\title{
Atrial fibrillation and thrombophilia. DOAC as a valid alternative? A clinical case
}

\section{Claudia Morabito ${ }^{a}$, Matteo Casale ${ }^{b}$, Pasquale Crea $^{a}$, Silvia Morabito ${ }^{a}$, Luca Zappiaa, Roberto Licordaria, Nunzio Antonio Giovanni Ficheraa, Arianna D'Angelo ${ }^{a}$, Alessandro Migliorato ${ }^{a}$, Francesco Luzzaa, Giuseppe Dattiloa}

a Department of Clinical and Experimental Medicine, University of Messina, Messina, Italy

b Operative Unit of ICCU and Cardiology Hospital, "S. Maria della Misericordia", ASUR Marche - Area Vasta 1, Urbino, Italy

\section{ARTICLE INFO}

\section{Article history:}

Submitted: 30.6 .2020

Accepted: 5. 7. 2020

Available online: 22. 10. 2020

\section{Klíčová slova:}

Edoxaban

Fibrilace síní

Př́má perorální antikoagulancia

Trombofilie

\section{SOUHRN}

Perorální antikoagulace znamenala revoluci v léčbě fibrilace síní (FS). Ve složitých případech, včetně některých typů trombofilií jako postižení zvyšujících riziko tromboembolie, může být warfarin neúčinný. Ukázalo se, že prímá perorální antikoagulancia (direct oral anticoagulants, DOAC) jsou plně hodnotnou možností léčby; jako účinný a bezpečný se osvědčil zvláště edoxaban. Popisujeme případ muže s FS a trombofilií, $u$ něhož došlo přes antikoagulační léčbu warfarinem $k$ vytvoření trombu v oušku levé síně; následně byla zahájena léčba edoxabanem.

(c) 2020, ČKS

\section{ABSTRACT}

Keywords:

Atrial fibrillation

Direct oral anticoagulants

Edoxaban

Thrombophilia

\begin{abstract}
Oral anticoagulation is a milestone in the management of atrial fibrillation (AF). In complex settings, involving some kinds of thrombophilia, a condition predisposing to higher risk of thromboembolism, warfarin can be ineffective. Direct oral anticoagulants (DOACs) demonstrated to be a valid therapeutic option; in particular edoxaban proved to be effective and safe. We show the case of a man with AF and thrombophilia who developed a thrombus in the left atrial appendage (LAA) despite anticoagulant therapy with warfarin, subsequently treated with edoxaban.
\end{abstract}

\section{Introduction}

Atrial fibrillation (AF) is the most common cardiac arrhythmia, with greater prevalence in older people. ${ }^{1}$ It is associated with increased risk of mortality and morbidity especially due to stroke; in fact $20-30 \%$ of all strokes are due to atrial fibrillation. ${ }^{1}$ Oral anticoagulation is a milestone in the management of $A F$, reducing stroke and mortality in these patients. ${ }^{1}$ However, management could be challenging in particular situations such as thrombophilia, a condition predisposing to a higher risk of thromboembolism, ${ }^{2}$ sometimes leading to resistance to vitamin $\mathrm{K}$ antagonists (VKAs) ${ }^{3,4}$ Direct oral anticoagulants (DOACs) can be a therapeutic option for stroke prevention in patients with non-valvular AF. ${ }^{1}$ Among these, edoxaban, a factor-
-Xa inhibitor, has demonstrated to be non-inferior to warfarin in terms of efficacy and safety. $2,5,6$

We show the case of a man with $\mathrm{AF}$ and thrombophilia who developed a thrombus in the left atrial appendage (LAA) despite anticoagulant therapy with warfarin, subsequently treated with edoxaban.

\section{Case report}

A 76-year-old man was admitted to our hospital because of a transient ischemic attack (TIA). In his clinical history he complained at 35 years of an episode of mild psoriasis in his elbows, successfully treated with topical therapy. At 50 years he had an episode of deep vein thrombosis treated with warfarin. In the same period a stress echo- 
cardiogram, performed because of atypical chest pain, was normal. From 15 years before he had a diagnosis of hypertension and atrial fibrillation (AF), leading to persistent treatment with warfarin..$^{7-13} \mathrm{He}$ was assuming a beta-blocker (bisoprolol 2,5 mg od) and an ACE-inhibitor (enalapril $10 \mathrm{mg}$ od). An electrocardiogram showed AF with a mean heart rate of 100 beats per minute (Fig. 1A). Blood tests revealed an international normalized ratio (INR) of 2,3. A transthoracic echocardiography showed a normal left ventricular volume and ejection fraction (LVEF) and a dilated left atrium (LA) with severe spontaneous echocontrastographic effect. A transesophageal echocardiogram (TEE) showed a partially mobile disorganized formation $(10 \times 13 \mathrm{~mm})$ suggestive of thrombus in the left atrial appendage (LAA) (Fig. 2A), despite anticoagulant therapy.

The checked of blood tests of the past 6 months demonstarted a time in therapeutic range (TTR) ${ }^{14}$ of $69 \%$ (Fig. 1B): this excluded a poor compliance to treatment and food or drug interactions with VKAs. Therapy with intravenous heparin was started and investigations for lupus anticoagulant, anti-cardiolipin antibodies, anti beta ${ }_{2}$-glicoprotein antibodies, $\mathrm{C}$ protein and factor $\mathrm{V}$ of Leiden. A diagnosis of heterozygous factor $\mathrm{V}$ of Leiden was made. ${ }^{15-23}$ After 1 week of treatment, we performed another TEE, which showed persistence of the thrombotic mass in the LAA (Fig. 2B). Some days after his clinical conditions improved and he was discharged with the indication to replace warfarin with edoxaban $60 \mathrm{mg}$ once daily.
At the 1-month follow-up he reported no clinically relevant bleeding and a TEE revealed the absence of the thrombus (Fig. 2C). At the next follow-up he continued to be in good clinical conditions: no thromboembolic nor bleeding were reported. We suggested LAA percutaneous occlusion because of the high risk of thromboembolism but he refused.

\section{Discussion}

This case underlines the role of thrombophilia in increasing the risk for thromboembolism. In fact our patient, who had heterozygosity for factor $\mathrm{V}$ Leiden mutation (a genetic disorder characterized by a low response to activated protein C), ${ }^{20-23}$ developed a thrombus in the LAA despite therapy with warfarin.

One may speculate that, in this patient, resistance to protein $C$ could have promoted a paradoxical pro-coagulant effect of warfarin conversely to its therapeutic anticoagulant effect. ${ }^{3}$ Warfarin, as a vitamin $\mathrm{K}$ antagonist (VKA), works indirectly on various coagulation factors and also on protein $C$, that has a significant role in coagulation cascade. ${ }^{24} \mathrm{~A}$ TTR almost in the range allows to exclude other possible causes but some oscillations could explain, in a case of thrombophilia, occurrence of thrombotic phenomena. ${ }^{20-23}$ The choice of intravenous heparin, even if was not successful, was considered appropriate because the patient developed a thrombus despite ther-

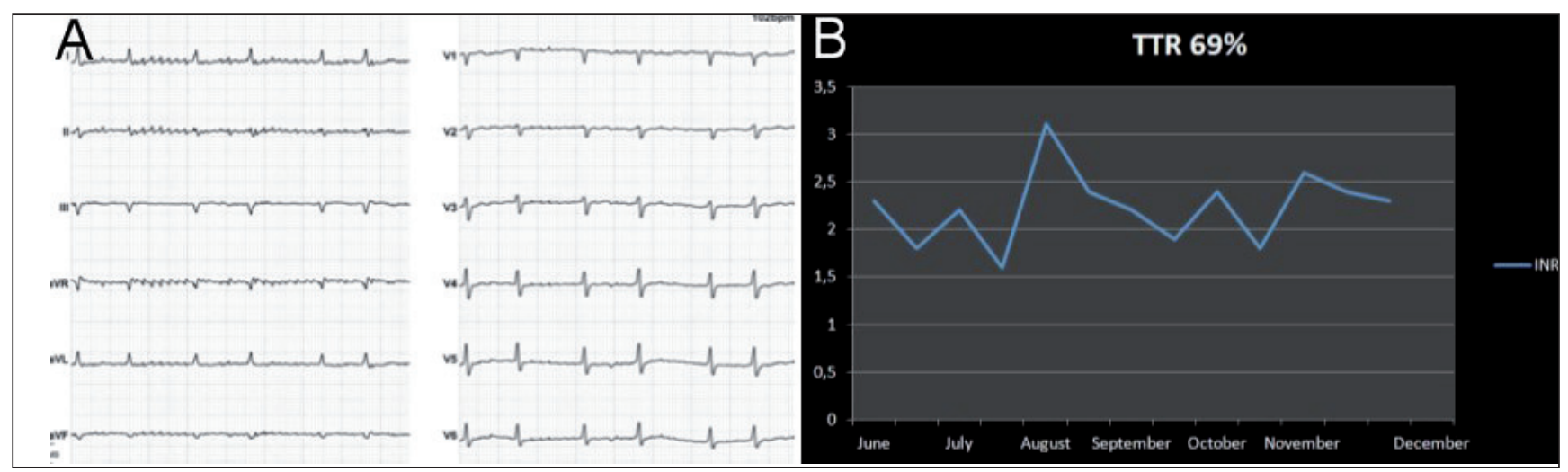

Fig. 1 - (A) Atrial fibrillation with a mean ventricular frequency $100 \mathrm{bpm}$. (B) Graphical representation of INR values in the last six months with time in therapeutic range (TTR) calculation.

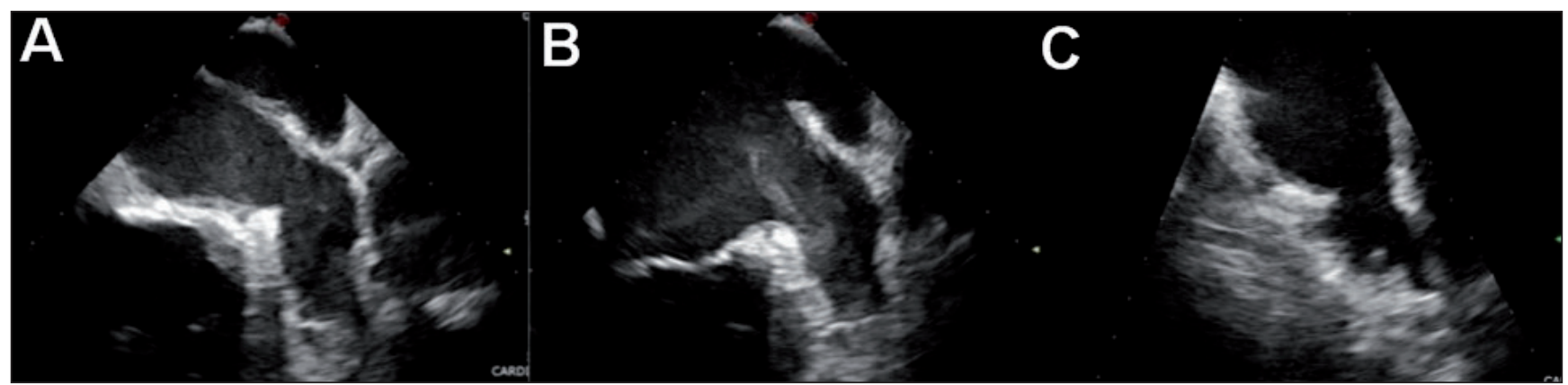

Fig. 2 - (A) Transesophageal echocardiogram showing a partially disorganized mobile formation in the LAA. (B) Transesophageal echocardiogram showing permanence of the thrombotic mass in LAA after a week of heparin treatment. (C) Transesophageal echocardiogram repeated after one month revealed the thrombus disappearance after therapy with edoxaban. 
apy with warfarin, needing for optimal anticoagulation control and because in literature there are several cases of low molecular weight heparin failure. ${ }^{15-18}$

DOAC are often preferred to other anticoagulants because they show rapid onset and offset of action, fewer drug interactions and dietary restriction; in addiction, their predictable anticoagulant effects allow to administrate fixed doses without requirement of routine coagulation monitoring. ${ }^{25,26}$ These favourable characteristics, simplifying treatment, improve adherence to therapy.

We decided to switch the anticoagulant treatment from warfarin to intravenous heparin for one week and then, for long-term, to edoxaban, a DOAC introduced in 2015 and approved for the prevention of stroke and systemic thromboembolism in patients with non-valvular AF. ${ }^{26}$ ENGAGE AF-TIMI 48 trial, a three-group, a randomized double blind trial, demonstrated in these patients non inferiority to warfarin of two dose regimens of edoxaban associated with a significant lower bleeding rate and lower death from cardiovascular causes. ${ }^{6}$

Little is known about the use of DOAC in thrombophilia. Some studies, such as Hokusai trial, compared warfarin with edoxaban and suggested no differences in the efficacy and safety of DOACs regardless of the type of thrombophilia. ${ }^{2}$ In our case edoxaban proved to be effective not only for preventing thrombus formation but also for favouring thrombus resolution when therapy with warfarin failed. Moreover it resulted safe because of absence of haemorrhagic complications.

\section{Conclusions}

In complex settings, involving some kinds of thrombophilia, warfarin can be ineffective. DOACs, and in particular edoxaban, demonstrated to be a safe and valid therapeutic option. Further investigations in subgroups of patients with AF and thrombophilia are needed to better understand the mechanisms that can cause the effectiveness of DOAC compared to VKA.

\section{Conflict of interest}

None.

\section{Funding body}

None.

\section{References}

1. Kirchhof P, Benussi S, Kotecha D, et al. 2016 ESC Guidelines for the management of atrial fibrillation developed in collaboration with EACTS. Eur Heart J 2016;37:2893-2962.

2. Serrao A, Lucani B, Mansour D, et al. Direct Oral Anticoagulants in Patients Affected by Major Congenital Thrombophilia. Mediterr J Hematol Infect Dis 2019;11:e2019044.

3. Scarano M, Casale M, Mantini C, et al. Rivaroxaban as an effective alternative to warfarin in a patient with atrial fibrillation, thrombophilia, and left atrial appendage thrombus: a case report. J Med Case Rep 2017;11:97.

4. Haastrup P, Rudbæk T, Bove J. Resistance to warfarin in a patient with hereditary thrombophilia. Ugeskr Laeger 2013;175:2572-2573.
5. Dattilo G, Falanga G, Casale M, et al. Oral Anticoagulants: Old and New Therapy. In: Berhardt LV (Ed.) Advances in Medicine and Biology. Volume 83. New York: Nova Science Publishers, Inc., 2015:13-70.

6. Giugliano RP, Ruff CT, Braunwald E, et al. Edoxaban versus warfarin in patients with atrial fibrillation. ENGAGE AF-TIMI 48 Investigators. N Engl J Med 2013;369:2093-2104.

7. Dattilo G, Lamari A, Scarano M, et al. Coronary artery disease and psoriasis. Minerva Cardioangiol 2014;62:119-121.

8. Imbalzano $\mathrm{E}$, Casale M, D'Angelo $\mathrm{M}$, et al. Cardiovascular risk and psoriasis: a role in clinical cardiology? Angiology 2015:66:101-103.

9. Dattilo G, Borgia F, Guarneri C, et al. Cardiovascular Risk in Psoriasis: Current State of the Art. Curr Vasc Pharmacol 2019;17:85-91.

10. Dattilo G, Imbalzano E, Casale M, et al. Psoriasis and Cardiovascular Risk: Correlation Between Psoriasis and Cardiovascular Functional Indices. Angiology 2018;69:31-37.

11. Imbalzano $\mathrm{E}$, Vatrano $\mathrm{M}$, Mandraffino $\mathrm{G}$, et al. Arterial stiffness as a predictor of recovery of left ventricular systolic function after acute myocardial infarction treated with primary percutaneous coronary intervention. Int J Cardiovasc Imaging 2015;31:1545-1551.

12. Dattilo G, Imbalzano E, Lamari A, et al. Ischemic heart disease and early diagnosis. Study on the predictive value of 2D strain. Int J Cardiol 2016;215:150-156.

13. Dattilo $G$, Patanè $S$, Zito $C$, et al. Handgrip exercise associated with dobutamine stress echocardiography. Int J Cardiol 2010;143:298-301.

14. Gateman D, Trojnar ME, Agarwal G. Warfarin anticoagulationfor atrial fibrillation in a community-based practice. Can Fam Physician 2017;63:e425-e431.

15. Tulino D, Imbalzano E, Casale $M$, et al. Treatment failure of low molecular weight heparin in diabetic patient. Int J Cardiol 2013;168):e63-e64.

16. Dattilo G, Lamari A, Di Bella G, et al. Treatment failure of low molecular weight heparin bridging therapy. Int J Cardiol 2013;167:e106-e107.

17. Patanè $S$, Marte $F$, Risica $G$, et al. Treatment failure of low molecular weight heparin bridging therapy before a cardiac surgery intervention in a patient with atrial fibrillation. Int J Cardiol 2009;137:e59-e60.

18. Dattilo G, Tulino D, Lamari A, et al; Treatment failure of low molecular weight heparin in a patient with an aortic mechanical prosthesis. Int J Cardiol 2011;146:e30-e32.

19. Roswell RO, Greet B, Shah S, et al. Intravenous Heparin Dosing Strategy in Hospitalized Patients With Atrial Dysrhythmias. J Thromb Thrombolysis 2016;42:179-185.

20. Kujovich JL. Factor V Leiden thrombophilia. Genet Med 2011;13:1-16.

21. Khalife S, Bissar-Tadmouri N. Inherited Thrombophilia in a Lebanese Family of Four Generations: A Case Report of Recurrent Miscarriage. Vasc Health Risk Manag 2020;16:53-56.

22. Dautaj A, Krasi G, Bushati V, et al. Hereditary thrombophilia. Acta Biomed 2019;90(10-S):44-46.

23. Mensa M, Dobbs T, Jessop ZM, et al. Homozygous Factor V Leiden Thrombophilia in a Patient With Histologically Confirmed Thromboangiitis Obliterans. Clin Med Insights Case Rep 2019;12:1179547619828719.

24. Kim Y, Bang OY. Paradoxical Procoagulant Effect of Early Doses of Warfarin: Possible Role of Non-Vitamin K Oral Anticoagulant in Patients with Atrial Fibrillation-Related Stroke. J Stroke 2015;17:216-218.

25. Colleen MH, Kowey PR. Are the novel anticoagulants better than warfarin for patients with atrial fibrillation? J Thorac Dis 2015;7:165-171.

26. Brown JD, Shewale AR, Talbert JC. Adherence to Rivaroxaban, Dabigatran, and Apixaban for Stroke Prevention for Newly Diagnosed and Treatment-Naive Atrial Fibrillation Patients: An Update Using 2013-2014 Data. J Manag Care Spec Pharm 2017;23:958-967. 